\title{
Immunodetection of Luteinizing Hormone (LH), Follicle-Stimulating Hormone (FSH), Thyroid Stimulating Hormone (TSH) and Prolactin (PRL) in Brachionus calyciflorus (Rotifera: Monogononta)
}

\author{
Jesús Alvarado-Flores ${ }^{1}$, María Del Rosario Montoya-Garcia ${ }^{2}$, Javier Ventura Juárez ${ }^{3} \&$ Roberto \\ Rico-Martínez ${ }^{4}$ \\ 1. Centro de Ciencias Básicas, Universidad Autónoma de Aguascalientes, Avenida Universidad 940, Aguascalientes, \\ C.P. 20100, México; jalvaflo@yahoo.com.mx \\ 2. Departamento de Fisiología y Farmacología, Universidad Autónoma de Aguascalientes, Avenida Universidad 940, \\ Aguascalientes, 20100, México; rosariomg2003@yahoo.com.mx \\ 3. Dpto. de Morfología, Centro de Ciencias Básicas, Universidad Autónoma de Aguascalientes, Avenida Universidad \\ 940, C.P. 20100, Aguascalientes, Aguascalientes, México; jventur@correo.uaa.mx \\ 4. Centro de Ciencias Básicas, Departamento de Química, Universidad Autónoma de Aguascalientes, Avenida \\ Universidad 940, Aguascalientes, C. P. 20100, México; rrico@correo.uaa.mx
}

Received 29-XI-2008. C Corrected 06-III-2009. Accepted 07-IV-2009.

\begin{abstract}
The endocrine system controls and coordinates behavioral, biochemical, and physiological processes through signal mechanisms using neuropeptides or products of neurosecretory cells. Among invertebrates, this system is poorly studied in rotifers, in which estrogens and androgens significantly affect sexual reproduction. This is the first report of the presence of the Luteinizing Hormone (LH), Follicle-Stimulating Hormone (FSH), Thyroid Stimulating Hormone (TSH) and Prolactin (PRL) in rotifers. Analyses included the avidin-biotin-peroxidase complex method with primary antibodies LH (Anti-Rat LH serum for RIA), PRL (Anti-Rat PRL serum for RIA), FSH (Anti-Rat FSH serum for RIA) and TSH (Anti-Rat TSH serum for RIA). These hormones were found in females, males and parthenogenetic and sexual eggs of the freshwater Brachionus calyciflorus. The immunoreactivity of FSH, LH, TSH and PRL in females was observed in: ovaries, cerebrum, mastax, stomach, lorica, and the stomach gland. However, in males LH was observed only at the trochal disk and cerebrum. The hormones FSH, TSH and PRL, were observed in testicles, contractil vesicles, and cementary gland of males. Regarding amictic or parthenogenetic eggs, the hormones LH, FSH, TSH, and PRL were located mainly in the micromeres, and the staining in the macromeres was weak. On the other hand, in the mictic or sexual eggs the inner shell is stained for the hormones PRL and LH, opposite to the staining of FSH and TSH, located mainly in the embryo. In general, immuno-reactivity was observed in areas important for the reproductive, excretory, digestive and developmental processes. Rev. Biol. Trop. 57 (4): 1049-1058. Epub 2009 December 01.
\end{abstract}

Keywords: Gonadotropic hormones, lactogenic hormones, thyroid hormones, Rotifera, invertebrates.

The endocrine system controls and coordinates behavioral, biochemical, and physiological processes through signal mechanisms using neuropeptides or products of neurosecretory cells specialized in this system. Among invertebrates, this system has been mostly studied in coelenterates, nematodes, mollusks, annelids, crustaceans, insects, echinoderms, and tunicates (Wigham et al. 1975, Terakado et al.
1997, Pinder et al. 1999, Wheeler 2003, Wilhem 2006, Hutchinson 2007). In rotifers, there is evidence that estrogens and androgens affect significantly sexual reproduction. Among the hormones tested for its effects on population growth in rotifers are: gama-aminobutiric acid, growth hormone, human chorionic gonadotropic hormone, estradiol, triiodothyronine, 20-hydroxyecdisone, 5-hydroxytryptamine, 
and juvenile hormone (Gallardo et al. 1997, 2000, Preston et al. 2000).

The catecholaminergic and cholinergic system of several rotifer species has been studied by several authors (Nogrady \& Alai 1983, Raineri 1984, Kotikova 1995, 1998, Kotikova et al. 2005, Pineda-Rosas et al. 2005), who have identified acethylcholinesterase activity and its receptors were described and the general characteristics of these systems were corroborated. The cholinergic system is involved in the reproduction and the fertility control because some neuropeptides control the synthesis of selected glycoproteins like the luteinizing hormone (LH) and gonadotropin (Vijayan 1985). The presence of exocitotic proteins such as Sintaxin-1, Sintaxin-4, SNAP-23 and SNAP-25 in rotifers suggests a mechanism of neurosecretion via exocitotic vesicles of enzymes, and other molecules, like hormones, related to glandular secretions (Pérez-Legaspi et al. 2008) which are employed in diverse mechanisms. Snell \& Joaquim-Justo (2007), suggest that since rotifers are particularly sensitive to androgenic and anti-androgenic substances, their use as models to study the nature and the impact of substances that are potential endocrine disruptors.

The invertebrates have developed a great diversity of lifestyles combining larval formation, followed by a succession of different stages, metamorphosis, production of resting eggs or other kind of resting stages, which are not produced in vertebrates, it is evident that the endocrine systems of invertebrates is more diverse than that of vertebrates (Oehlmann \& Schulte-Oehlmann 2003). In fact, the unicellular protozoan Tetrahymena pyriformis contains several types of molecules, which are immunologically similar to the glycoprotein hormones of the human pituitary gland (FSH, LH, and $\mathrm{TSH}$ ), and that treatment with these molecules induced production of the appropriate hormone, and this effect is transmitted to the progeny generations (Csaba \& Kovács 2000). Likewise, TSH has been identified in the annelid Eisenia fetida, in both neuronal and non-neuronal cells of the central nervous system and several peripheral organs (Di Fiore et al. 1997). Furthermore, there have been reports of the presence of TSH receptors in several invertebrates: Caenorhabditis elegans (nematode), the fruit fly, Drosophila melanogaster and the freshwater gastropod Limnaea stagnalis (Tensen et al. 1994, Hauser et al. 1997, Eriksen et al. 2000, Kudo et al. 2000).

Several authors reported the presence of PRL in invertebrates. Quintanar et al. (2007a) found PRL in larval stages of the nematode Trichinella spiralis, in the nervous and reproductive systems of cestodes: Ligula intestinalis (Liu et al. 1995), Taenia solium and Taenia hydatigena (Liu et al. 1996), and it has been found in granules of neurons in insects: Leucophaena maderae (Veenstra et al. 1985), Apis mellifera (Schmid et al. 1990), Locusta migratoria and Sarcophaga bullata (Swinnen et al. 1990).

However, the presence, function, and distribution of hormones in rotifers have been poorly studied (see Wallace et al. 2006). Therefore, the goal of this contribution is to demonstrate the presence of the gonadotropic hormones; Luteinizing Hormone (LH) and Follicle-Stimulating Hormone (FSH), the thyroid hormone, Thyroid Stimulating Hormone (TSH) and the lactogenic hormone, Prolactin (PRL) in females, males, parthenogenetic and mictic eggs of the freshwater rotifer Brachionus calyciflorus.

\section{MATERIALS AND METHODS}

Rotifer collection and culture: The freshwater rotifer Brachionus calyciflorus (Pallas 1766) was collected from the water treatment pond of the Universidad Autónoma de Aguascalientes, Mexico, geographic coordinates of this site have been already published (PérezLegaspi \& Rico-Martínez 1998). The rotifer was cultured according to the protocol of Pérez-Legaspi \& Rico-Martínez (1998). Such protocol implies the use of a bioclimatic chamber with a 16:8 dark:light period and a temperature of $25 \pm 2^{\circ} \mathrm{C}$, where the rotifers were kept in Petri dishes with EPA medium 
(U.S. Environmental Protection Agency 1985). Rotifers were fed with the green alga Nannochloris oculata (strain LB2194 of the University of Texas Collection) grown in Bold's Basal Medium (Nichols 1973). Typically 10-15 Petri dishes containing each from 100 to 500 rotifer females were kept.

Rotifer embedding: Rotifers were collected from cultures, 500 to 1000 amictic females of different ages (without making distinctions) for this species in $1.0 \mathrm{ml}$ of EPA medium by transferring them into a microcentrifuge tube of $1.5 \mathrm{ml}$ and added $100 \mu 1$ of $10 \%$ formalin solution for 30min to sacrifice and fix animals. Subsequently they were centrifuged at $4000 \mathrm{rpm}$ to eliminate the supernatant and then we add drop by drop $2 \%$ liquid agar into the rotifer pellets until they became hard. Then the rotifer-agar-pellets were fixed in $5 \mathrm{ml}$ of $3 \%$ formalin plus Bouin's fixative solution (saturated aqueous picric acid solution, 37-40\% formalin, and glacial acetic acid, according to McElroy et al. 1994). After one-hour fixation the rotifer-agar-pellet were rinsed in water for one hour, dehydrated in a series of ethanol solutions $(80,96,100 \%$ for 20,30 and $30 \mathrm{~min}$, respectively), and ethanol plus xylol (1:1) for $30 \mathrm{~min}$, and $100 \%$ xylol for $25 \mathrm{~min}(2 \mathrm{x})$. Subsequently one paraffin drop plus $1.0 \mathrm{mg}$ of sudan IV was added for one hour at $58^{\circ} \mathrm{C}$. Finally the rotifers were transferred into $100 \%$ paraffin liquid at $56^{\circ} \mathrm{C}$ for $12 \mathrm{hr}$. Then $3 \mu \mathrm{m}$ thick sections were cut by a microtome and the section were fixed to microscope slides, the sections were stained with hematoxylin and eosin, and examined under a compound light microscope as morphological reference.

Immunohistochemical method: To demonstrate immunoreactivity of the LH, FSH, TSH and PRL hormones, the avidin-biotinperoxidase complex method was practiced (Hsu et al. 1981), using the kit (Vectastin ABC kit, Dimension Laboratories Inc., CA, U.S.A.) with slight modifications (Quintanar et al. 2007b). Primary antibodies LH (AntiRat LH serum for RIA), PRL (Anti-Rat PRL serum for RIA), FSH (Anti-Rat FSH serum for RIA) and TSH (Anti-Rat TSH serum for RIA) were used at 1:20, 1:30, 1:50 and 1:100 dilutions, respectively; which are intermediate values according to manufacturer's suggestion and previous results (Salinas et al. 2004). All samples exposed to primary antibodies were incubated at $4^{\circ} \mathrm{C}$ overnight. The peroxidase complex was visualized by incubating the sections with $0.05 \%$ diaminobenzidine and $0.01 \%$ $\mathrm{H}_{2} \mathrm{O}_{2}$. Slides were positive with immunohistochemistry staining showing a brown dark color, negative slides showed no color.

\section{RESULTS}

The results of the Brachionus calyciflorus immunodetection experiments are shown in figures 1 to 4 that correspond to females (Fig. 1), male (Fig. 2), amictic egg (Fig. 3) and mictic egg (Fig. 4).

Female: Control rotifers were stained with hematoxylin-eosin (sagittal cut, Fig. 1B) where several structures can be observed: muscular bands $(\mathrm{Mb})$, cerebrum $(\mathrm{Ce})$, pharynx $(\mathrm{Ph})$, stomach gland (Sg), lorica ( $\mathrm{Lg})$, mastax (M), cerebral eye (E), dorsal palp (Dp), trophi (Tr), and vitellum (Vt). In Fig. 1C (transversal cut) the positive immunoreactivity to $\mathrm{FSH}$, in stomach (St), stomach gland (Sg), contractile gland $(\mathrm{Cg})$, trophi $(\mathrm{Tr})$, and vitellum $(\mathrm{Vt})$ is shown. Positive immunoreactivity to TSH is shown in Fig. 1D (sagittal cut) in cerebrum: (Ce), lorica (Lg), mastax (M), trophi (Tr), and vitellum (Vt). Positive immunoreactivity to $\mathrm{LH}$ is shown Fig. 1E (transversal cut) in: cerebrum (Ce), stomach (St), stomach gland (Sg), lorica $(\mathrm{Lg})$, and mastax (M). Positive immunoreactivity to PRL is shown in Fig. 1F (sagittal cut) in: cerebrum $(\mathrm{Ce})$, stomach $(\mathrm{St})$, stomach gland $(\mathrm{Sg})$, lorica $(\mathrm{Lg})$, mastax $(\mathrm{M})$, trophi $(\mathrm{Tr})$, and vitellum $(\mathrm{Vt})$, the latest one being the most stained.

Male: Control males were stained with hematoxylin-eosin (saggital cut, Fig. 2B) where it is possible to observe muscular bands $(\mathrm{Mb})$, 

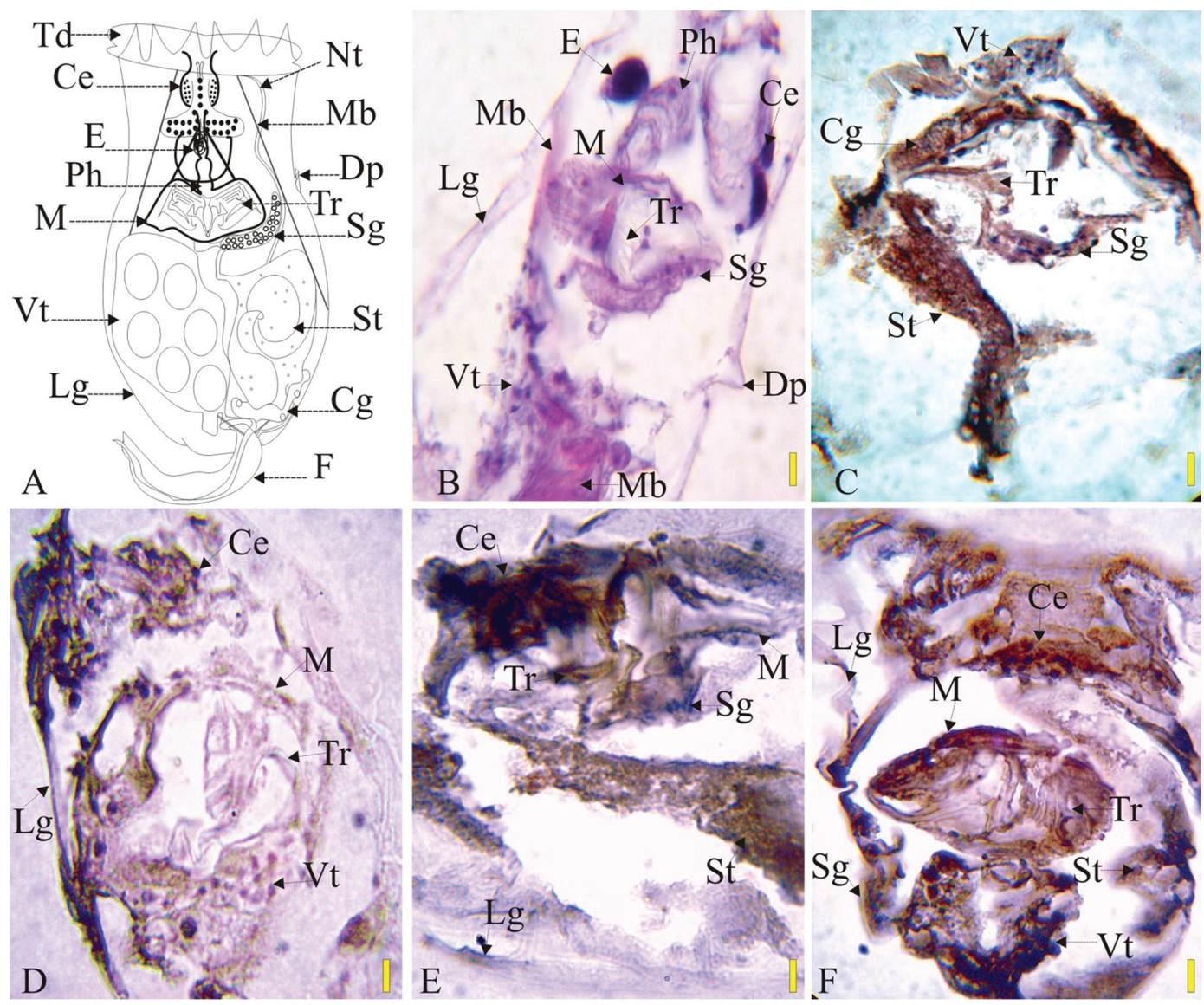

Fig. 1. Results of the experiments in Brachionus calyciflorus females. (A) main structures of a typical Brachionus calyciflorus female as observed in the light microscope. (B) saggital cut of a control animal stained with hematoxylin and eosine. (C) transversal cut showing positive immunoreactivity to FSH. (D) saggital cut showing positive immunoreactivity to TSH. (E) Transversal cut showing positive immunoreactivity to LH. (F) revealing positive immunoreactivity to PRL, saggital cut. All images were contrasted with hematoxylin.

Abbreviations: muscular bands (Mb), cerebrum (Ce), trochal disk (Td), stomach (St), pharynx (Ph), stomach gland (Sg), cementary gland $(\mathrm{Cg})$, loriga $(\mathrm{Lg})$, mastax $(\mathrm{M})$, cerebral eye $(\mathrm{Ce})$, foot $(\mathrm{F})$, dorsal palp $(\mathrm{Dp})$, nephridial tubes $(\mathrm{Nt})$, trophi (Tr), vitellum (Vt). The yellow bar at the posterior margin of each figure equals $20 \mu \mathrm{m}$.

trochal disk $(\mathrm{Td})$, penis $(\mathrm{Pe})$, testicles $(\mathrm{T})$, and contractile vesicle $(\mathrm{Cv})$. The Fig. 2C (sagital cut) shows positive immunoreactivity for $\mathrm{FSH}$ in trochal disk $(\mathrm{Td})$, cement gland $(\mathrm{Cg})$, testicles $(\mathrm{T})$, and contractile vesicle $(\mathrm{Cv})$. In Fig. 2D (sagital cut) shows positive immunoreactivity to TSH in trochal disk (Td), contractile vesicle $(\mathrm{Cv})$, and testicles $(\mathrm{T})$. The Fig. 2E (sagital cut) shows positive immunoreactivity to $\mathrm{LH}$ trochal disk (Td), and cerebrum (Ce). In Fig. 2F (sagital cut) there is positive immunoreactivity to PRL in cerebrum $(\mathrm{Ce})$, cement gland $(\mathrm{Cg})$, contractile vesicle $(\mathrm{Cv})$, and testicles $(\mathrm{T})$, the latest one being the most intense.

Parthenogenetic Egg: Control eggs were stained with hematoxylin-eosin (transversal cut, Fig. 3B) showing different types of cells: macromeres $(\mathrm{Ma})$, micromeres $(\mathrm{Mi})$, and the nuclei $(\mathrm{Nu})$. In Fig. 3C (transversal cut) there is positive immunoreactivity to FSH very weak in the macromeres (Ma), but very strong in 

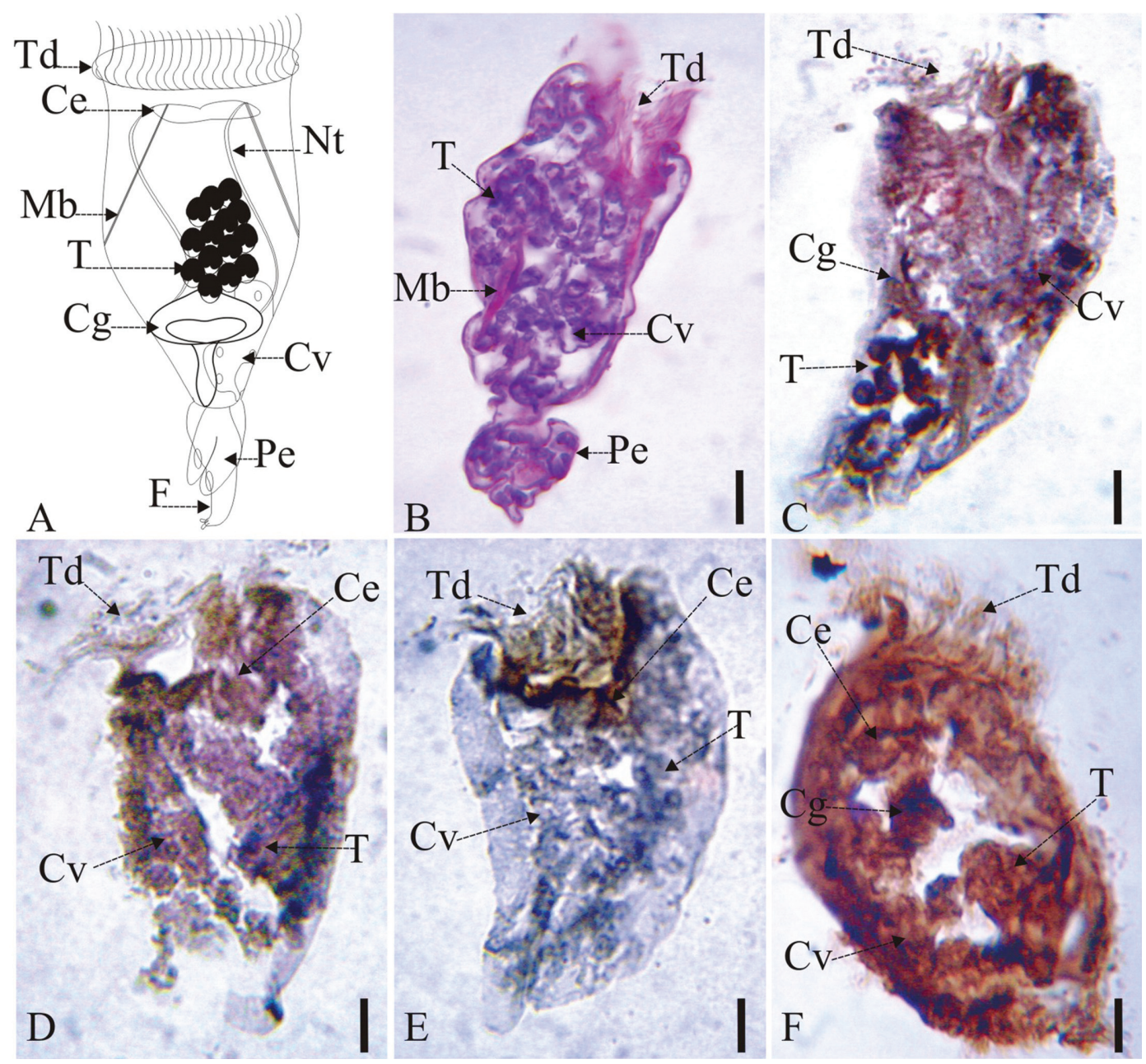

Fig. 2. Results of the experiments in Brachionus calyciflorus males. (A) main structures of a typical Brachionus calyciflorus male as observed in the light microsocpe. (B) saggital cut of a control male stained with hematoxylin and eosine. (C) saggital cut showing immunoreactivity to FSH. (D) saggital cut demonstrating positive immunoreactivity to TSH. (E) saggital cut showing positive immunoreactivity to LH. (F) saggital cut showing positive immunoreactivity to PRL. All images were contrasted with hematoxylin.

Abbreviations: muscular bands $(\mathrm{Mb})$, cerebrum $(\mathrm{Ce})$, trochal disk $(\mathrm{Td})$, cementary gland $(\mathrm{Cg})$, foot $(\mathrm{F})$, nephridial tubes $(\mathrm{Nt})$, penis $(\mathrm{P})$, contractile vesicle $(\mathrm{Cv})$. The black bar at the posterior margin of each figure equals $10 \mu \mathrm{m}$.

micromeres (Mi), especially in the nuclei $(\mathrm{Nu})$. In Fig. 3D (transversal cut) there is positive immunoreactivity to TSH in macromeres (Ma), micromeres (Mi), and nuclei $(\mathrm{Nu})$. In Fig. 3E (transversal cut) there is positive immunoreactivity to $\mathrm{LH}$ in macromeres (Ma), micromers (Mi), and nuclei $(\mathrm{Nu})$. The Fig. 3F (transversal cut) shows immunoreactivity to PRL in macromeres (Ma), and micromeres (Mi) the latest one being the most intense.

Mictic Egg: Control sexual eggs were stained with hematoxylin-eosin (transversal cut, Fig. 4B) showing the outer shell (Os), inner shell (Is), and embryo (E). The Fig. 4C (transversal cut) shows positive immunoreactivity 

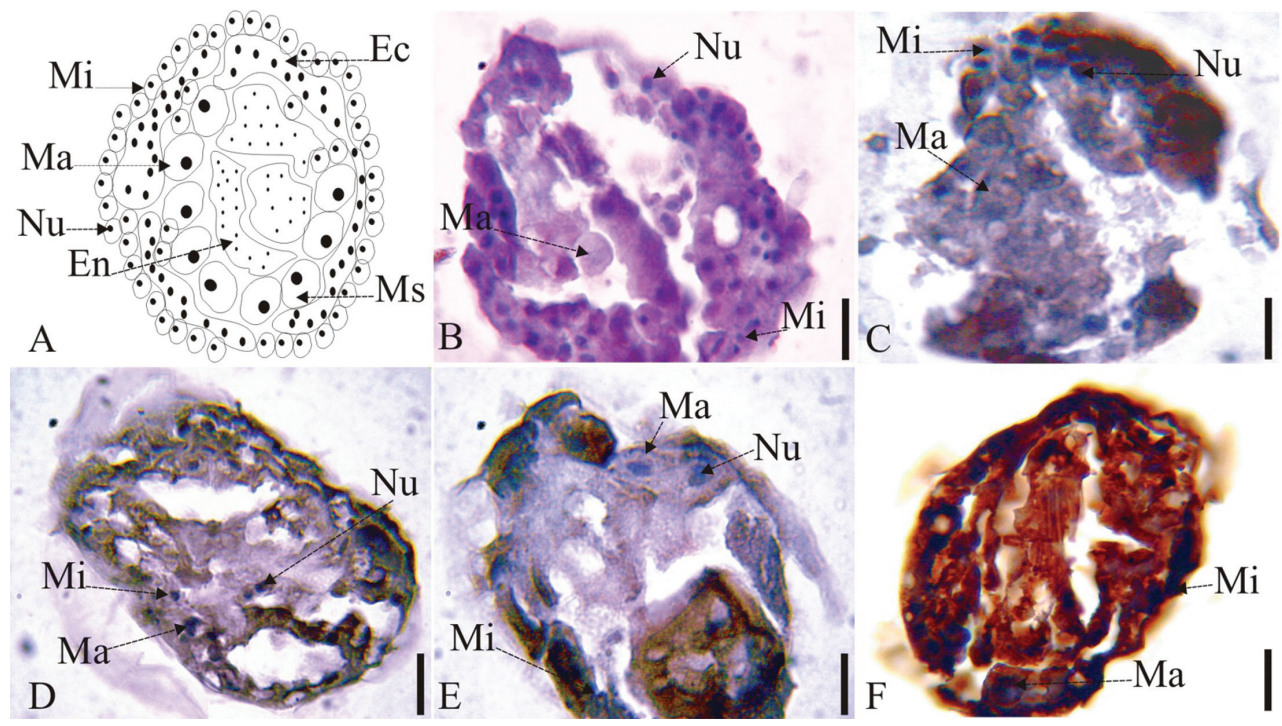

Fig. 3. Results of the experiments with amictic eggs of Brachionus calyciflorus. (A) amictic egg showing the main structures as seen with the light microscope. (B) control egg stained with hematoxylin and eosine, transversal cut. (C) Positive immunoreactivity to FSH, transversal cut. (D) Positive immunoreactivity to TSH, transversal cut. (E). Positive immunoreactivity to LH, transversal cut (F). Positive immunoreactivity to PRL, transversal cut. All images were contrasted with hematoxylin. Abbreviations: ectoderm (Ec), endoderm (En), macromere (Ma), micromere (Mi), mesoderm (Ms), nucleus (Nu). The black bar at the posterior margin of each figure equals $10 \mu \mathrm{m}$.

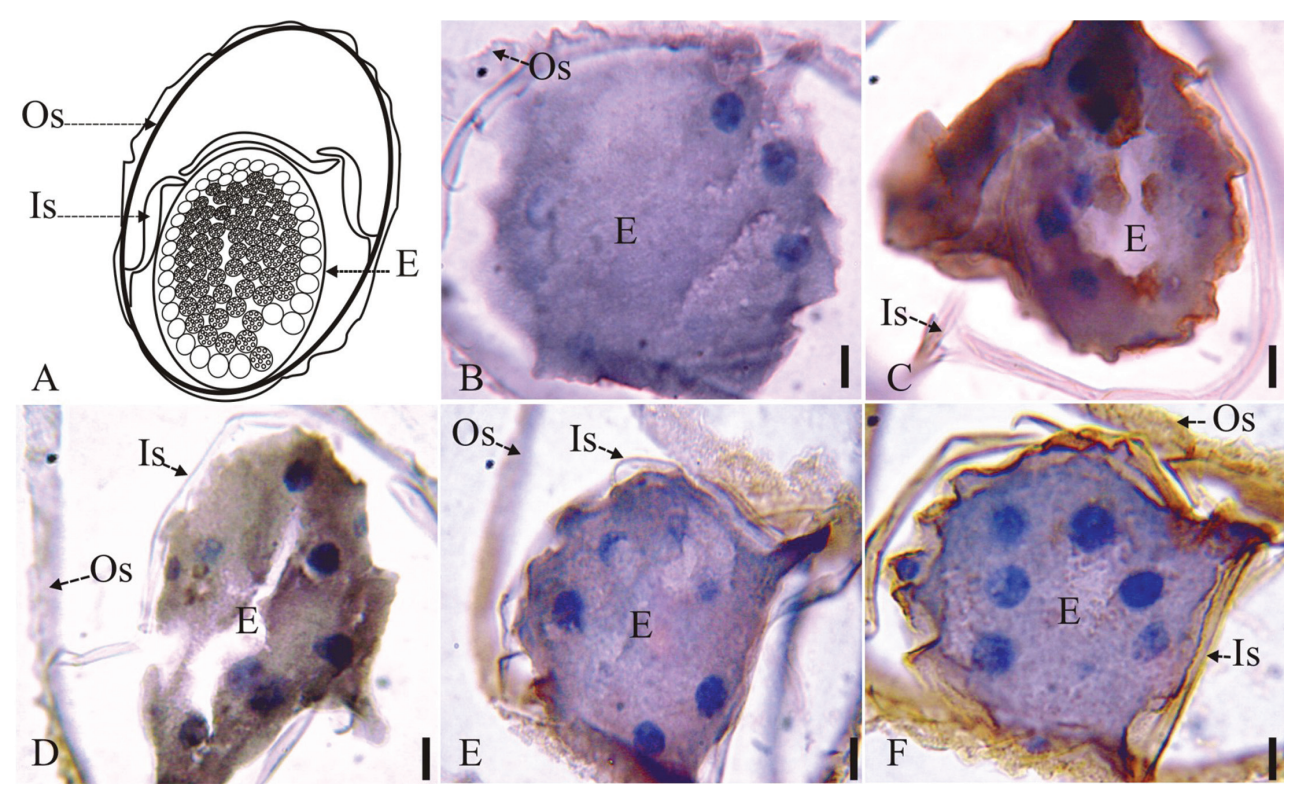

Fig. 4. Results of the experiments with mictic eggs of Brachionus calyciflorus. (A) mictic egg showing the main structures as seen with the light microscope. (B) control egg stained with hematoxylin and eosine, transversal cut. (C) Positive immunoreactivity to FSH, transversal cut. (D) Positive immunoreactivity to TSH, transversal cut. (E) Positive immunoreactivity to LH, transversal cut. (F) Positive immunoreactivity to PRL, transversal cut. All images were contrasted with hematoxylin. Abbreviations: embryo (E), inner shell (Is), and outer shell (Os). The black bar at the posterior margin of each figure equals $10 \mu \mathrm{m}$. 
to FSH in the inner shell (Is), and the embryo (E). In Fig. 4D (transversal cut) there is positive immunoreactivity to TSH in the outer shell (Os) and embryo (E). The Fig. 4E (transversal cut) shows positive immunoreactivity to $\mathrm{LH}$ in the outer shell (Os) and in the inner shell (Is). In Fig. 4F (transversal cut) there is positive immunoreactivity to PRL in the outer shell (Os), inner shell (Is), and embryo (E).

\section{DISCUSSION}

Our contribution represents the first report of the presence of the Luteinizing Hormone (LH), Follicle-Stimulating Hormone (FSH), Thyroid Stimulating Hormone (TSH) and Prolactin (PRL) in rotifers. These hormones were found in females, males and parthenogenetic and sexual eggs of the freshwater Brachionus calyciflorus. The immunoreactivity of FSH, LH, TSH and PRL in females was observed in ovaries, cerebrum, mastax, stomach, loriga, and the stomach gland. However, in males LH is observed only at the trochal disk and cerebrum. The hormones FSH, TSH and PRL, are observed in testicles, contractil vesicles, and cementary gland of males.

Regarding amictic or parthenogenetic eggs, the hormones LH, FSH, TSH, and PRL are located mainly in the micromeres, and the staining in the macromeres is weak. On the other hand, the mictic or sexual eggs the inner shell is stained for the hormones PRL and $\mathrm{LH}$, opposite to the staining of FSH and TSH, located mainly in the embryo.

In general, the immunoreactivity was observed in areas important for the reproductive, excretory, digestive and developmental processes. These areas stained for the hormones match the areas where the colinergic and catecolaminergic systems have been reported (Nogrady \& Alai 1983, Raineri 1984, Kotikova, 1995, 1998, Kotikova et al. 2005, Pineda-Rosas et al. 2005). Furthermore, in these areas there have been already reports of the presence of exocitotic proteins in rotifers, suggesting the presence of a cholinergic system coupled to a hormone release system (Pérez-Legaspi et al. 2008).

What is the function of these hormones in rotifers? When $\mathrm{T}_{3}$ was added to algal food, there were no effects in the population growth of Brachionus plicatilis, but produced size reduction in females (Gallardo et al. 1997). Since TSH stimulates the production of $\mathrm{T}_{3}$ and $\mathrm{T}_{4}$, perhaps the rotifer can use this hormone to reduce female size as a mechanism to avoid predation by visual predators or as a response to any other environmental clue that favors size reduction in females.

The presence of LH and FSH in amictic and mictic eggs of $B$. calyciflorus suggests their influence in the embryologic development in this rotifer. The presence of $\mathrm{LH}$ and FSH in females and males in areas like ovaries, testicles and vitellum suggest its influence in gonadic development and reproduction.

The hormone PRL has been located by immunohistochemical techniques in glandular regions of neuronal cells of the sea pineapple Halocynthia roretzi (Terakado et al. 1997). PRL has been described as very active inducing cell proliferation and differentiation of multiple tissues in humans (Coppenolle et al. 2004). Perhaps, PRL has a similar function in rotifers stimulating cell proliferation and differentiation. That function would fit right with their ample distribution in females, males and both types of eggs that were found in $B$. calyciflorus.

The response of the ovaries of crustaceans to the presence of FSH and LH from mammals, indicates that such hormones can act in similar ways in invertebrates (Zukowska-Arendarczyk 1981). Both hormones stimulate the synthesis and secretion of sexual steroids in the gonads of vertebrates. For examples, LH stimulates the synthesis and secretion of testosterone that later transforms into estrogens. High concentrations of LH induce the formation of mature follicles in the ovary. Similarly, FSH stimulates the maturation process of follicles and of sperm (Kawauchi \& Sower 2006). It is noteworthy to point out that rotifers responded to exposure to several androgenic agents by reducing the 
fertilization rate and sexual reproduction (Preston et al. 2000, Snell \& Joaquim-Justo 2007). As more information on the catecholaminergic and cholinergic systems of aquatic invertebrates (and the hormone secretion systems attached to them), is unveiled, the more it will be possible to know about the mode of action and mechanisms of detoxification of these animals that could be used as toxicity models.

\section{ACKNOWLEDGMENTS}

Sincere gratitude to Alejandro PerezLegaspi and José Luis Quintanar-Stephano for their valuable support in the development of this research, and to Rosa Isela Sandoval for methodological support.

\section{RESUMEN}

Se logró detectar la presencia de las hormonas: Hormona Luteinizante (LH), Hormona Folículo Estimulante (FSH), Hormona Estimulante de la Tiroides (TSH) y Prolactina (PRL) en Brachionus calyciflorus siendo el primer reporte de la presencia de dichas hormonas en rotíferos. Estas hormonas fueron identificadas por un método inmunológico-histológico-químico usando el complejo avidina-biotina-peroxidasa con los siguientes anticuerpos primarios: LH (Anti-Rata LH suero para RIA), PRL (Anti-Rata PRL suero para RIA), FSH (Anti-Rata FSH suero para RIA) y TSH (Anti-Rata TSH en suero para RIA). Estas hormonas se encontraron en las hembras, machos, huevos partenogenéticos y huevos sexuales del rotífero dulceacuícola $B$. calyciflorus. La reactividad inmunológica de FSH, LH, PRL y TSH en las hembras se observó en ovarios, cerebro, mástax, estómago, lorica, y la glándula del estómago. Sin embargo, en machos, la LH se observó sólo en el disco trocal y cerebro mientras que las hormonas FSH, PRL y TSH, se observaron en testículos, vesícula contráctil, y la glándula cementaria. En cuanto a los huevos partenogenéticos o amícticos, las hormonas LH, FSH, TSH, y PRL, se encontraron principalmente en los micrómeros, y en los macrómeros la tinción es débil. Por otra parte, el huevo sexual o míctico muestra reactividad inmunológica en la cubierta interior del huevo para las hormonas LH y PRL, lo contrario para FSH y TSH, las cuales se observaron principalmente en el embrión. La reactividad inmunológica fue observada, en general, en áreas importantes para los procesos reproductivos, excretorios, digestivos y del desarrollo.

Palabras claves: hormonas gonadotrofinas, hormonas lactogénicas, hormonas tiroideas, Rotífera, invertebrados.

\section{REFERENCES}

Coppenolle, V.F., R. Skryma, H. Ouadid-Ahidouch, C. Slomianny, M. Roudbaraki, P. Delcourt, E. Dewailly, S. Humez, A. Crépin, I. Gourdou, J. Djiane, J.L. Bonnal, B. Mauroy \& N. Prevarskaya. 2004. Prolactin stimulates cell proliferation through a long form of prolactin receptor and $\mathrm{K}+$ channel activation. $\mathrm{J}$. Biochem. 377: 569-578.

Csaba, G. \& P. Kovács. 2000. Human Chorionic Gonadotropin (HCG)-like Hormones (FSH, LH, TSH) in Tetrahymena. A Confocal Microscopic Analysis. Acta Protozool. 39: 191-198.

Di Fiore, M.M., L. Perrone \& A. D’Aniello. 1997. Presence of humanlike thyroid stimulating hormone (TSH) in Ciona intestinalis. Life Sci. 61: 623-629.

Eriksen, K.K., F. Hauser, M. Schiott, K.M. Pederson, L. Sondergaard \& C.J.P. Grimmelikhuijzen. 2000. Molecular cloning, genomic organization, developmental regulation, and a knock-out mutant of a novel leu-rich repeats-containing $\mathrm{G}$ protein-coupled receptor (DLGR-2) from Drosophila melanogaster. Genome Res. 10: 924-938.

Gallardo, G.W., A. Hagiwara, Y. Tomita, K. Soyano \& W.T. Snell. 1997. Effect of some vertebrates and invertebrate hormones on the population growth, mictic female production, and body size of the marine rotifer Brachionus plicatilis Müller. Hydrobiologia 358: 113-120.

Gallardo, G.W., A. Hagiwara \& T. W. Snell. 2000. GABA enhances reproduction of the rotifer Brachionus plicatilis Muller: application to mass culture. Aquacult. Res. 31: 713-718.

Hauser, F., H.P. Nothacker \& C.J. Grimmelikhuijzen. 1997. Molecular cloning, genomic organization, and developmental regulation of a novel receptor from Drosophila melanogaster structurally related to members of the thyroid stimulating hormone, folliclestimulating hormone, luteinizing hormone/ choriogonadotropin receptor family from mammals. J. Biol. Chem. 272: 1002-1010.

Hsu, S.M., L. Raine \& H. Fagner. 1981. The use antividin antibody and avidin-biotin peroxidasa complex in inmunoperoxidasa technics. Am. J. Clin. Pathol. 75: 816-821.

Hutchinson, T.H. 2007. Smalls useful in endocrine disrupter assessment-four key recommendations for aquatic invertebrates research. Ecotoxicology 16: 231-238.

Kawauchi, H. \& S.A. Sower. 2006. The dawn and evolution of hormones in the adenohypophysis. Gen. Comp. Endocrinol. 148: 3-14. 
Kotikova, E.A. 1995. Localization and neuroanatomy of catecholaminergic neurons in some rotifers species. Hydrobiologia 313/314: 123-127.

Kotikova, E.A. 1998. Catecholaminergic and neuroanatonomy of rotifers. Hydrobiologia 387/388: 135-140.

Kotikova, E.A., O.I. Raikova, M. Reuter \& M.K.S. Gustafsson. 2005. Rotifer nervous system visualized by FMRF amide and 5-HT inmunocytochemistry and confocal laser scanning microscopy. Hydrobiologia 546: 239-248.

Kudo, M., T. Chen, K. Nakabayashi, S.Y Hsu \&A.J Hsueh. 2000. The nematode leucine-rich repeat-containing, $\mathrm{G}$ protein-coupled receptor (LGR) protein homologous to vertebrate gonadogtropin and thyrotropin receptors is constitutively active in mammalian cells. Mol. Endocrinol. 14: 272-284.

Liu, B., H. Wakuri \& K. Mutoh. 1995. Immunocytochemical evidence for the presence of prolactin in the plerocercoid of Ligula intestinalis (Cestoda: Pseudophyllidea). Okajimas folia Anat. Jpn. 72: 277-283.

Liu, B., H. Wakuri \& K. Mutoh. 1996. Prolactin in the cestodes, Taenia solium and Taenia hydatigena: an immunocytochemical study. Okajimas Folia Anat. Jpn. 73: 25-35

McElroy, D.A. 1994. Connective tissue. p. 127-147. In E.B. Prophet, B. Mills, J.B. Arrington \& L.H. Sobin (eds.). Armed Forces Institute of Phatology Laboratory Methods in Histotechnology, Washington D.C., USA.

Nichols, H. W. 1973. Growth media-freshwater, p.7-24. In J. R. Stein (ed). Handbook of physiological methods. Cambridge, Massachussets, USA.

Nogrady, T. \& M. Alai. 1983. Cholinergic neurotransmission in rotifers. Hydrobiologia 104: 149-153.

Oehlmann, J. \& U. Schulte-Oehlmann. 2003. Endocrine disruption in invertebrates. Pure Appl. Chem. 75: 2207-2218.

Pérez- Legaspi, I. A. \& R. Rico-Martínez. 1998. Effect of temperature and food concentration in two species of littoral rotifers. Hydrobiologia 387/388: 341-348.

Pérez-Legaspi, I. A., M. R. Montoya-García, J. L. Quintanar, E. Salinas, \& R. Rico-Martínez. 2008. Identification of exocytotic membrane proteins in three rotifer species. Hydrobiologia 600: 147-154.

Pinder, L.C.V., T.G. Pottinger, Z. Billinghurst \& M.H. Depledge. 1999. R\&D Technical Report E67. Endocrine function in aquatic invertebrates and evi- dence for disruption by environmental pollutants. Environment Agency Rio House. Bristol, United Kingdom.

Pineda-Rosas, A., G.E. Santos-Medrano., M.F. ZavalaReynoso \& R. Rico-Martínez. 2005. Identification of acetilcholinesterase receptors in Rotifera. Hydrobiologia 546: 249-253.

Preston, B.L., T.W. Snell, T.L. Robertson \& B.J. Dingmann. 2000. Use of freshwater rotifer Brachionus calyciflorus in screening assay for potential endocrine disruptors. Environ. Toxicol. Chem. 19: 2923-2928.

Quintanar, J.L., E. Salinas, R. Guerrero, R. Gómez, S. Vidal, J. Aranda \& C. Clapp. 2007a. Prolactin-like hormone in the nematode Trichinella spiralis larvae. Exp. Parasitol. 116: 137-141.

Quintanar J.L., E. Salinas \& R. González. 2007b. Expression of gonadotropin-releasing hormone receptor in cerebral cortical neurons of embryos and adult rats. Neurosci. Lett. 411: 22-25.

Raineri, M. 1984. Histochemical investigation of Rotifera Bdelloidea. I. Localization of cholinesterase activity. Histochem. J. 16: 601-616.

Salinas, E., J. Ventura, L.E. Córdova \& J.L. Quintanar. 2004. Presence of SNAP-25 in rat mast cells. Immunol. Lett. 95: 105-108.

Schmid, K.P., V. Maier, C. Haug \& E.F Pfeiffer. 1990. Ultrastructural localization of prolactin-like antigenic determinants in neurosecretory cells in the brain of the honeybee (Apis mellifica). Horm. Metab. Res. 22: 413-417.

Swinnen, K., J.V. Broeck, P. Verhaert \& A. De Loof. 1990. Immunocytochemical localization of human growth and prolactin-like antigenic determinants in the insects, Locusta migratoria and Sarcophaga bullata. Comp. Biochem. Physiol. 95: 373-378.

Snell, T.W. \& C. Joaquim-Justo. 2007. Workshop on rotifers in ecotoxicology. Hydrobiologia 593: 227-232.

Tensen, C.P, E.R Van Kasteren, R.J Planta, K.J Cox, J.F Burke, H. van Heerikhuizen \& E. Vreugdenhil. 1994. A G protein coupled receptor with low-density lipoprotein-bindig motifs suggests a role for lipoproteins in G-linked signal transduction. Proc. Natl. Acad. Sci. USA 91: 4816-4820.

Terakado, K., M. Ogawa, K. Inoue, K. Yamamoto \& S. Kikuyama. 1997. Prolactin-like immunoreactivity in the granules of neural complex cells in the ascidian Halocynthia roretzy. Cell. Tissue. Res. 289: 63-71. 
U.S.EPA. 1985. Methods for measuring the acute toxicity of effluents to freshwater and marine organisms. Environmental Monitoring and Support Laboratory, U.S. Environmental Protection Agency, Cincinnati, Ohio, USA.

Veenstra, J.A., H.M. Romberg-Privee, H. Schooneveld \& J.M. Polak. 1985. Immunocytochemical localization of peptidergic neurons and neurosecretory cells in the neuro-endocrine system of the Colorado potato beetle with antisera to vertebrate regulatory peptides. Histochem. 82: 9-18.

Vijayan, E. 1985. Role of neurotransmiter and neuropeptides in the control of gonadotropin release: a review. J. Biosci. 2: 207-213.

Wallace, R.L., Snell T.W., C. Ricci \& T. Nogrady. 2006. Rotifera. 1: Biology, ecology and systematic, Kenobi Productions, Ghent, Belgium.
Wheeler, E.D. \& H.F. Nijhout. 2003. A perspective for understanding the modes of juvenile hormone action as a lipid signaling system. BioEssays 25: 994-1001.

Wigham, T., J.N. Ball \& P.M. Ingleton. 1975. Secretion of prolactin and growth hormone by teleost pituitaries in vitro. J. Comp. Physiol. 104: 87-96.

Wilhelm, M., A. Koza, P. Engelmann, P. Németh \& Csoknya M. 2006. Evidence for the presence of thyroid-stimulating hormone, thyroglobulin and their receptors in Eisenia fetida: a multilevel hormonal interface between the nervous system and the peripheral tissues. Cell. Tissue. Res. 324: 535-546.

Zukowska-Arendarczyk, M. 1981. Effect of hypophyseal gonadotropins (FSH and $\mathrm{LH}$ ) on the ovaries of the sand shrimp Crangon crangon (Crustacea: Decapoda). Mar. Biol. 63: 241-247. 